A N N A L E S

UNIVERSITATIS M ARIAE CURIE-SKŁODOW K A

L UBLIN - P OLONIA

VOL. LXIII, 2

SECTIO C

2008

\author{
ANNA HALKIEWICZ \\ Department of Hydrobiology, University of Life Sciences in Lublin, \\ Dobrzańskiego 37, 20-262 Lublin \\ e-mail: anna.halkiewicz@up.lublin.pl
}

\title{
New and rare subfossil records of Chironomidae (Diptera) in Poland
}

Subfosylne znaleziska nowych i rzadkich taksonów Chironomidae (Diptera) w Polsce

\section{SUMMARY}

Subfossil material isolated from the surface bottom sediment cores (length: 40-70 cm) collected in five shallow Polesie lakes was analysed for the presence of subfossil chironomids remains.

Amongst the recorded chironomid taxa Labrundinia longipalpis Goetghebuer, turned out to be new for Poland, and six taxa are new (Corynocera ambigua Zetterstedt, Microchironomus Kieffer, Propsilocerus Kieffer, Stempellina Thienemann and Basse, Stenochironomus Kieffer, Zavreliella Kieffer) or rare (Lauterborniella agrayloides Kieffer, Limnophyes Eaton, Parakiefferiella Thienemann) for Lublin Polesie. The paper presents ecology and distribution of the taxa, as well as the age of the sediment layers in which they were found.

\section{STRESZCZENIE}

Analizowano rdzenie osadów dennych (dług. 40-70 cm) z pieciu płytkich jezior poleskich pod kątem zawartości subfosylnych szczątków Chironomidae. Wśród stwierdzonych taksonów jeden Labrundinia, okazał się nowy dla Polski, 6 taksonów nowych (Corynocera ambigua, Microchironomus, Propsilocerus, Stempellina, Stenochironomus, Zavreliella) oraz 3 rzadkie (Lauterborniella, Limnophyes, Parakiefferiella) na Polesiu Lubelskim. W pracy podano ekologię i rozmieszczenie taksonów oraz wiek warstw osadów, w których je stwierdzono.

Keyw ords: Chironomidae, paleolimnology new records, Lublin Polesie, Poland 


\section{INTRODUCTION}

The aim of this research was to reconstruct the past habitat conditions taking place in the selected lakes in the Lublin Polesie in the period of recent few centuries. An object of this study was subfossil remains of chironomids, which have been very seldom studied in Poland so far $(9,24,13,15)$. This paper presents new and rare taxa of chironomids from which one turned out to be new for Poland, six are new and three rare for the Lublin Polesie.

\section{STUDY AREA AND METHODS}

The research was carried out in five lakes: Kleszczów, Rotcze, Sumin, Głębokie Uścimowskie



The lakes are relatively shallow $(2.9-6.4 \mathrm{~m})$ and small (6-50 ha), representing a trophic status from mezo- to hypertrophy (Tab.1). They differ in respect of the level of the development of submerged macrophytes, from lakes with extensive underwater meadows to one deprived of submerged vegetation (21).

Table 1. Morphometric characteristics of the lakes, Secchi Disc visibility (SD), development of submerged macrophytes, expressed as PVI coefficient (percent of lake water volume infested) and trophic status (accoroling to Kornijów et al. 2002) (21)

\begin{tabular}{lccccc}
\hline Lake & Kleszczów & Rotcze & Sumin & G. Uścimowskie & Syczyńskie \\
\hline Surface area [ha] & 50 & 46 & 86 & 20 & 6 \\
Max. depth [m] & 3 & 4,3 & 6.5 & 6.4 & 2.9 \\
SD [m] & 2.4 & 2.5 & 1.6 & 0.9 & 0.3 \\
PVI [\%] & 29.3 & 34.5 & 3.3 & 0.75 & 0 \\
Trophic status & mesotrophy & mesotrophy & eutrophy & eutrophy & hypertrophy \\
\hline
\end{tabular}

Sediment cores of $0.4 \mathrm{~m}-0.7 \mathrm{~m}$ in length were taken from the deepest part of the lakes using a gravit Uwitec-corer equipped with a plexiglas tube of $120 \mathrm{~cm}$ in length and $6 \mathrm{~cm}$ in inner diameter.

The cores were sliced into $1 \mathrm{~cm}$ layers. Until the depth of $20 \mathrm{~cm}$, every slice was analysed, below that - every fifth. The samples were treated following the procedures by Warwick (31). The subfossil material was sieved through a $180-\mu \mathrm{m}$ screen.

The head capsules were identified according to Brooks (5), Wiederholm (32), and Rievadevall and Brooks (28). The majority of identifications were done to the genus level. The numbers of head capsules (HC) were converted into $10 \mathrm{~g}$ dry weight of the sediments. The age of the sediments was calculated on the basis of a constant rate of supply of unsupported ${ }^{210} \mathrm{~Pb}$ model by Gąsiorowski (12).

\section{RESULTS}

New taxon for Poland

\section{Labrundinia longipalpis Goetghebuer, 1921}

Labrundinia head capsules were found only in mesotrophic Lake Rotcze in six sediment layers (Tab. 2). 
Table 2. Distribution of Labrundinia remains found in sediment profile from Lake Rotcze

\begin{tabular}{l|c|c|c|c}
\hline Lake & $\begin{array}{c}\text { Sediment layer } \\
(\mathrm{cm})\end{array}$ & HC/10g DW sediments & $\begin{array}{c}\text { Relative abundance } \\
(\%)\end{array}$ & Age 210 Pb \\
\hline \multirow{5}{*}{ Rotcze } & 1 & 31 & 1.8 & 2002 \\
& 2 & 24 & 1.7 & \\
& 5 & 35 & 1.6 & \\
& 8 & 30 & 5.2 & 1955 \\
\hline
\end{tabular}

Habitat requirements of the larvae of Labrundinia are known very little. They are usually found in small, standing water bodies, but also in streams and rivers (32). Kornijów found the larvae in the Hudson river on the surface of Trapa natans (22). According to Fittkau \& Roback (11), the European species prefers bogs but lives in lake sediments samples, too. It is assumed to be an indicator of warm waters (1).

\section{New taxa for Lublin Polesie}

Corynocera ambigua Zetterstedt, 1838

Larval remains of Corynocera were encountered in four lakes: Kleszczów, Rotcze, Sumin and Głębokie Uścimowskie. Only in one profile from Lake Rotcze the taxon was present up to the top layers of the sediments. It may suggest that the species is still present in the lake. The detailed information about abundance of remains in the profiles and the time of their deposition are given in Halkiewicz (14).

Larvae of Corynocera occur in cold oligotrophic lakes in Norway and interstadial and early Holocene sediments from Scotland, Scandinavia and central Europe (5). For very long time the larvae have been considered as cold stenothermal glacial relic (27). However, the recent findings of the larvae in different types of lakes have put in doubt this opinion $(2,1)$.

\section{Microchironomus Kieffer, 1918}

The remains were present in sediments of three lakes: Rotcze, Sumin and Głębokie Uścimowskie. In Lake Rotcze the remains occurred solely in one layer and in a few ones in lakes Sumin and Głębokie Uścimowskie (Tab. 3).

Microchironomus usually occurs in the profundal of warm mesotrophic and eutrophic lakes $(3,4,6,16)$. Its ecology is known very little (10).

Propsilocerus lacustris Kieffer, 1923

The species was found only in one hypertrophic, phytoplankton-dominated Lake Syczyńskie in the following sediment layers: 1, 2, 7, 8, 14, $15 \mathrm{~cm}$. The detailed information about abundance of the remains in the profile is presented 
in Kornijów and Halkiewicz (20). The authors suggest that $P$. lacustris might be a good indicator of hypertrophic conditions.

Table 3. Distribution of Microchironomus remains in sediment profiles from lakes: Rotcze, Sumin and Głębokie Uścimowskie

\begin{tabular}{|l|c|c|c|c|}
\hline Lake & $\begin{array}{c}\text { Sediment layer } \\
(\mathrm{cm})\end{array}$ & HC/10g DW sediments & $\begin{array}{c}\text { Relative abundance } \\
(\%)\end{array}$ & Age 210 Pb \\
\hline Rotcze & 14 & 12 & 6 & 1961 \\
\hline \multirow{5}{*}{ Sumin } & 9 & 10 & 25 & 1997 \\
& 13 & 8 & 10 & 1982 \\
& 15 & 11 & 14 & 1965 \\
& 17 & 8 & 3 & \\
& 20 & 6 & 6 & 1810 \\
\hline \multirow{5}{*}{ G. Uścimowskie } & 30 & 8 & 7 & 1985 \\
& 35 & 15 & 2 & 1975 \\
& 11 & 4 & 4 & 1949 \\
\hline
\end{tabular}

Stempellina Thienemann and Basse, 1913

Taxon found only in two mesotrophic lakes: Kleszczów and Rotcze. In Lake Rotcze remains were present in one, while in Kleszczów in three layers (Tab. 4).

It is considered as a warm stenotherm $(7,30)$ abundantly occurring especially in oligotrophic lakes $(7,3)$ including oligrotrophic tropical dam reservoirs $(23)$.

Table 4. Distribution of Stempellina remains in sediment profiles from lakes Kleszczów and Rotcze

\begin{tabular}{|l|c|c|c|c|}
\hline Lake & $\begin{array}{c}\text { Sediment layer } \\
(\mathrm{cm})\end{array}$ & HC/10g DW sediments & $\begin{array}{c}\text { Relative } \\
\text { abundance } \\
(\%)\end{array}$ & Age 210 Pb \\
\hline Kleszczów & 45 & 35 & 8 & ca. 1735 \\
\hline \multirow{3}{*}{ Rotcze } & 20 & 14 & 2 & 1925 \\
& 40 & 12 & 4 & $>$ before 1860 \\
& 45 & 8 & 7 & > before 1860 \\
\hline
\end{tabular}

Stenochironomus Kieffer, 1921

Remains were found in three lakes: Kleszczów, Rotcze and Sumin. In Lake Sumin the taxon was present in only one layer, in Rotcze in four, and in Sumin in two layers (Tab. 5).

The larvae mine living and dead macrophytes and also wooden debris (26). They occur in mesotrophic and eutrophic lakes (3). 
Table 5. Distribution of Stenochironomus remains in sediment profiles from lakes Kleszczów, Rotcze, and Sumin

\begin{tabular}{l|c|c|c|c}
\hline Lake & $\begin{array}{c}\text { Sediment layer } \\
(\mathrm{cm})\end{array}$ & HC/10g DW sediments & $\begin{array}{c}\text { Relative abundance } \\
(\%)\end{array}$ & Age 210 Pb \\
\hline Kleszczów & 40 & 15 & 6 & ca. 1770 \\
\hline \multirow{4}{*}{ Rotcze } & 6 & 31 & 2 & 1991 \\
& 12 & 13 & 3 & \\
\hline \multirow{2}{*}{ Sumin } & 17 & 23 & 6 & 1931 \\
\hline
\end{tabular}

Zavreliella Kieffer, 1920

The remains were found only in Lake Głębokie Uścimowskie on the one level (Tab. 6).

Table 6. Distribution of Zavreliella remains in sediment profile from Lake Głębokie Uścimowskie

\begin{tabular}{l|c|c|c|c}
\hline Lake & $\begin{array}{c}\text { Sediment layer } \\
(\mathrm{cm})\end{array}$ & $\begin{array}{c}\text { HC/10g DW } \\
\text { sediments }\end{array}$ & $\begin{array}{c}\text { Relative abundance } \\
(\%)\end{array}$ & Age $210 \mathrm{~Pb}$ \\
\hline G. Uścimowskie & 6 & 10 & 5 & 1997 \\
\hline
\end{tabular}

The genus is worldwide in distribution, with the greatest number of species in tropical South America. The larvae live amongst macrophytes (26). Z. marmorata is the only species of this genus known in Europe (29).

Rare taxa for Lublin Polesie

Lauterborniella agrayloides (Kieffer, 1911)

Larvae remains of Lauterborniella agrayloides were found in three lakes: Rotcze, Sumin and Głębokie Uścimowskie.

Table 7. Distribution of Lauterborniella agrayloides remains in sediment profiles from lakes Rotcze, Sumin, and Głębokie Uścimowskie

\begin{tabular}{l|c|c|c|c}
\hline Lake & $\begin{array}{c}\text { Sediment layer } \\
(\mathrm{cm})\end{array}$ & $\begin{array}{c}\text { HC/10g DW } \\
\text { sediments }\end{array}$ & $\begin{array}{c}\text { Relative abundance } \\
(\%)\end{array}$ & Age 210 Pb \\
\hline Rotcze & 18 & 22 & 8 & 1939 \\
\hline Sumin & 55 & 7 & 0.7 & $<1810$ \\
\hline \multirow{2}{*}{ G. Uścimowskie } & 15 & 9 & 6 & 1989 \\
\hline
\end{tabular}

Lauterborniella lives in littoral habitats, in relatively warm, eutrophic lakes (6). Larvae can also be found in oligotrophic lakes (3). L. agrayloides is the only species known in Holarctic (29).

In Polesie region the species was found on submerged vegetation in mesotrophic Lake Piaseczno and in eutrophic Lake Głębokie near Cyców $(17,18,19)$. 
Limnophyes Eaton, 1875

The remains were found in Lake Głębokie Uścimowskie in two, and in Lake Syczyńskie lakes, in two and in one sediment layers respectively (Tab. 8).

Table 8. Distribution of Limnophyes remains in sediment profiles from lakes Głębokie Uścimowskie and Syczyńskie

\begin{tabular}{l|c|c|c|c}
\hline Lake & $\begin{array}{c}\text { Sediment layer } \\
(\mathrm{cm})\end{array}$ & $\begin{array}{c}\text { HC/10g DW } \\
\text { sediments }\end{array}$ & $\begin{array}{c}\text { Relative abundance } \\
(\%)\end{array}$ & Age 210 Pb \\
\hline G. Uścimowskie & 7 & 5 & 3 & 1995 \\
\hline Syczyńskie & 11 & 4 & 2 & 1985 \\
\hline
\end{tabular}

The genus inhabits both streams and shallows in lake litoral (16). It can be useful to reconstruct water level fluctuations in lakes (25). The larvae of some species dwell aquatic macrophytes (3), others live in terrestrial or semiterrestrial habitats (8). In the Lublin Polesie it was found only in Lake Piaseczno (17).

Parakiefferiella Thienemann, 1936

Larval remains of Parakiefferiella were found in two lakes: Rotcze and Głębokie Uścimowskie, in each of them only once (Tab. 9).

Table 9. Distribution of Parakiefferiella remains in the sediment profiles from lakes Rotcze and Głębokie Uścimowskie.

\begin{tabular}{l|c|c|c|c}
\hline Lake & $\begin{array}{c}\text { Sediment layer } \\
(\mathbf{c m})\end{array}$ & $\begin{array}{c}\text { HC/10g DW } \\
\text { sediments }\end{array}$ & $\begin{array}{c}\text { Relative abundance } \\
(\mathbf{\%})\end{array}$ & Age 210 Pb \\
\hline Rotcze & 20 & 14 & 2 & 1925 \\
\hline G. Uścimowskie & 40 & 37 & 4 & ca. 1640 \\
\hline
\end{tabular}

Species of Parakiefferiella occur in litoral of temperate lakes (5) and in lotic habitats (32). There is very little information on its ecology (5). In Polesie lakes it was found only in mesotrophic Lake Piaseczno on submerged macrophytes $(17,19)$.

\section{ACKNOWLEDGEMENTS}

The study was supported by the State Committee for Scientific Research, project No 2 P06S 001 27. The author thanks Ryszard Kornijów, Ian Walker, Peter Cranston and Xinhua Wang for checking the identification of the larvae. 


\section{REFERENCES}

1. Barley E. M., Walker I. R., Kurek J., Cwynar L. C., Matthewes R. W., Gajewski., Finney B. 2006. A northwest north American training set: distribution of freshwater midges in relation to air temperature and lake depth. J. Paleolimnol. 36: 295-314.

2. Brodersen K. P., Lindegaard C. 1999. Mass occurrence and sporadic distribution of Corynocera ambigua Zettersted (Diptera, Chironomidae) in Danish lakes. Neo- and paleolimnological records. J. Paleolimnol. 22: 41-52.

3. Brodin Y. W. 1986. The postglacial history of Lake Flarken, southern Sweden, interpreted from Subfossil insect remains. Internat. Rev. ges. Hydrobiol. 71: 371-432.

4. Brooks S. J., Bennion H., Briks H. J. B. 2001. Tracing lake trophic history with a chironomidtotal phosphorus inference model. Freshw. Biol. 46: 513-533.

5. Brooks S. J., Langdon P. G., Heiri O. 2007. The identification and use of Palearctic Chironomidae larvae in paleoecology. Quaternary Research Association, London.

6. Brooks S., Udachin V., Williamson B. 2005. Impact of copper smelting on lakes in the southern Ural Moutains, Russia, inferred from chironomids. J. Paleolimnol. 33: 229-241.

7. Brundin L. 1949. Chironomiden und andere Bodentiere der sudschwedischen Urgebirgsseen. Rep. Inst. Freshwat. Res. Drottingholm 30: 1-914.

8. Cranston P. S., Oliver D. R., Seather O. A.1983. The larvae of Orthocladiinae (Diptera: Chironomidae) of Holarctic region. Keys and diagnoses. Entomol. Scand. Suppl. 19:149-291.

9. Czeczuga B., Kossacka W., Niedźwiedzki E. 1979. Ecological changes in Wigry Lake in the postglacial period, Part III: Investigations of the Chironomidae stratygraphy, Pol. Arch. Hydrobiol. 26 (3): 351-369.

10. Epler J. H. 2001. Identification Manual for the Larval Chironomidae (Diptera) of North and South Carolina. Division of Water quality. http://wire.enr.state.nc.us/esb/BAUwww/Chironomid.htm

11. Fittkau E. J., Roback S. S. 1983. The larvae of the Tanypodinae (Diptera: Chironomidae) of the Holarctic region - keys and diagnoses. Entomol. Scand. Suppl. 19: 33-110.

12. Gąsiorowski M. Deposition rate of sediments under different alternative stable states. Geochronologia. In press.

13. Halkiewicz A. 2005. Subfossil remains of Chironomidae from two shallow lakes representing extreme alternative states. Studia Quaternaria 22: 45-49.

14. Halkiewicz A. Corynocera ambigua (Insecta, Diptera) subfossils occurrence in recent sediments of four shallow Polesie lakes. Ann. UMCS, sec. C, Submitted.

15. Halkiewicz A., Kornijów R., 2006. Subfosylne szczątki Chironomidae zapisem współczesnej historii płytkiego jeziora, XX Zjazd Hydrobiologów Polskich, Toruń, 5-8 September, 27.

16. Kansanen P. H. 1985. Assessment of pollution history from recent sediments in LakeVanajavesi, southern Finland. II. Changes in Chironomidae, Chaoboridae and Ceratopogonidae (Diptera) fauna. Ann. Zool. Fen. 22:57-90.

17. Kornijów R. 1982. Nowe i rzadkie dla Polski gatunki Chironomidae (Diptera). Ann. UMCS, sec. C, 37: 133-136.

18. Kornijów R. 1988. Distribution of zoobenthos in littoral of two lakes differing in trophy. Pol. Arch. Hydrobiol. 35: 185-195.

19. Kornijów R. 1989. Macrofauna of elodeids of two lakes of different trophy I. Relations between elodeids and structure of fauna colonizing them. Ekol. Pol. 37: 31-48.

20. Kornijów R., Halkiewicz A. 2007. Are the larvae of Propsilocerus lacustris Kieffer 1923 (Diptera: Chironomidae) favoured by nutrient-rich lakes? Aquat. Ins. 29: 187-194. 
21. Kornijów R., Pęczuła W., Lorens B., Ligęza S., Rechulicz J., Kowalczyk-Pecka D. 2002. Shallow Polesie Lakes from the view point of the alternative stable states theory. Acta Agroph. 68: $61-72$.

22. Kornijów R., Strayer D., Caraco N.F. Macroinvertebrate communities of hypoxic habitats created by an invasive plant (Trapa natans) in the freshwater tidal Hudson River. J. N. Am. Benthol. Soc. Submitted.

23. Kornijów R., Szczerbowski J. A., Krzywosz T., Bartel R. 2001. The macrozoobenthos of the Iraqi lakes Tharthar, Habbaniya and Razzazah. Arch. Pol. Fish. 9, Suppl. 1: 125-143.

24. Kubovčík V. 2004. Chironomid tanatocenoses (Diptera: Chironomidae) in the sediments of the lakes of the Tatra Mts, Dipteron, 20: 21-22.

25. Massaferro J., Brooks S. J. 2002. The response of chironomids to Late Quaternary climate change in Taitao Peninsula, southern Chile. J. Quartern. Sci. 17:101-111.

26. Pinder L. C. V., Reiss F. 1983. The larvae of Chironominae (Diptera: Chironomidae) of Holarctic region - keys and diagnoses. In: Wiederholm T. (red.) Chironomidae of the Holarctic region. Keys and diagnoses. Part 1 - Larvae. Ent. Scand., Suppl. 19: 293-435.

27. Reiss F., Gerstmeier R. 1984. Corynocera anmbiqua Zetterstedt als Glazialrelikt im Starnberger See, Oberbayern. Nachricht. Bayer. Entomol. 33: 58-61.

28. Rieradevall M., Brooks S. 2001. An identification guide to subfossil Tanypodinae larvae (Insecta: Diptera: Chironomidae) based an cephalic setation. I. Paleolimnol. 25: 81-99.

29. Saether O. A., Spies M. 2004. Chironomidae. [In:] de Jong H. (ed.) Fauna Europea: Diptera, Nematocera. Fauna Europea version 1.1. http://www.faunaeur.org

30. Walker I. R., Smol J. P., Engstrom D. R., Briks H. J. B. 1991. Assessment of Chironomidae as quantitative indicators of past climatic change. Can. J. Fish. Aq. Sci. 48: 975-987.

31. Warwick W. F. 1980. Paleolimnology of the Bay of Quinte, Lake Ontario: 2800 years of cultural influence. Can. Bull. Fish. Aq. Sci. 206: 1-117.

32. Wiederholm T. (ed.) 1983. Chironomidae of the Holarctic region: keys and diagnoses. Part 1: Larvae. Entomol. Scand. Suppl. 19: 1-457. 